\title{
Towards an 'alternative' geography of innovation: alternative milieu, socio-cognitive protection and sustainability experimentation.
}

Final version accepted Environmental Innovation and Sustainability Transitions Dec 2014

Noel Longhurst

Science, Society and Sustainability research group

School of Environmental Sciences

University of East Anglia

Norwich

NR4 7TJ

n.longhurst@uea.ac.uk

\begin{abstract}
This paper highlights the hitherto unrecognised role of 'alternative' places in protecting different forms of sustainability innovation. The paper uses the concept of an alternative milieu to illustrate how a geographically localised concentration of countercultural practices, institutions and networks can create socio-cognitive 'niche' protection for sustainability experiments. An alternative milieu creates protection for the emergence of novelties by (i) creating ontological and epistemological multiplicity; (ii) sustain- ing productive spatial imaginaries; and (iii) supporting ontological security. These different dimensions of protection are explored with reference to an in-depth, empirical case study of Totnes in the United Kingdom. The paper concludes with some reflections on the theoretical implications of this research for the theorising of niche protection and for the geographies of innovation more generally, along with some recommendations for future areas of enquiry.
\end{abstract}

\section{Introduction}

Over the past decade there has been increasing interest in the complex co-evolution of socio-technical systems which deliver key societal functions such as energy and transport in late capitalist countries. In focusing on 'systems innovation', much of this work has sought to explore the conditions under which new radical sustainability innovations are able to 'break through' and 'scale up' displacing existing socio-technical systems. As such, a range of different theoretical tools have been developed to not only explain such processes, but also to be deployed in order to support the development of 'radical' technologies (see Markard et al. 2012, Grin et al., 2010, Smith et al., 2010, or Kemp, 2010 
for recent reviews of this literature). Within this literature, the concept of the protective niche has become a key theoretical metaphor. The idea that niches are significant in nurturing the development of new technologies has its root in evolutionary theories of technological change (Schot and Geels, 2007). Yet critical questions remain relating to how such protection should be understood and how it is created (Verhees et al., 2012; Raven, 2012; Smith and Raven, 2012).

Within research on sustainability transitions there is a growing body of work which argues that most literature has overlooked the significance of geography (Coenen et al., 2012; Coenen and Truffer, 2012; Bridge et al., 2013; Truffer and Coenen, 2012). These authors make a number of linked arguments. First, there is a need to understand the uneven spatiality of socio-technical transitions and the way in which they are simultaneously geographical and historical processes. Second, whilst transition theory borrows geographical concepts - 'space' and 'scale' being obvious examples - these are often underdeveloped particularly with reference to the relational turn within geography (Raven et al., 2012). Third, critics highlight the fact that (sub)disciplines such as economic geography and regional studies have already developed a number of concepts that may help to explain the uneven spatiality of transition processes, particularly related to sociospatial embeddedness. A spatially informed, co-evolutionary transition model would insist on the recognition that new 'green' niches arise from an inherently asymmetrical process of regional development (Truffer and Coenen, 2012). Accordingly, they suggest that a productive line of research would be to engage with how certain cities or regions provide protected 'spaces' for the emergence of sustainability innovations.

This paper seeks to contribute to both the theory surrounding the nature of niche protection and this growing body of work on geographies of transition. It does so by describing how a geographical alternative milieu can produce forms of protection for nascent sustainability experiments. The paper argues that the presence of an alternative milieu - a localised density of countercultural institutions, networks, groups and practices - 
creates a particular form of geographical protection for the emergence of different forms of sustainability experiment. Alternative milieu can provide a range of different kinds of support for experimentation, including financial and practical, but this paper focuses in particular on the way in which the milieu creates socio-cognitive space for new experiments to emerge, arguing that there are three dimensions to this protection: i) ontological and epistemological multiplicity; (ii) sustaining supportive spatial imaginaries; and (iii) creating ontological security. The way in which an alternative milieu can protect sustainability innovation is described with reference to a case study of an alternative milieu located in South Devon in the UK, focused around the town of Totnes. The paper proceeds as follows: Part two provides an overview of the theory relating to the geography of protective niches. Part three introduces the alternative milieu around Totnes and three examples of experimentation: grassroots innovation, market based innovation and conceptual innovation. Section four then describes the three dimensions of socio-cognitive space provided by the milieu. Finally, part five then draws together some conclusions, including some indications of areas of future inquiry.

\section{Geography of protective niches}

Strategic Niche Management (SNM) is the strand of sustainability transitions theory that helped to establish the concept of a protective niche (Kemp et al., 1998). Early proponents of SNM were interested in how technological niches could be constructed to provide protective space in which promising new 'green' experimental technologies, such as electric cars, could be developed and nurtured (Kemp et al., 1998; Hoogma et al., 2002). Niche has also become a central analytical category in the multi-level perspective (MLP), a heuristic designed to provide a tool for understanding socio-technical change over longer periods. Here the niche reflects one of three 'levels': niches, regimes and the landscape (Geels, 2002). The regime is the 'deep structure' which stabilises a particular socio-technical system (Geels, 2011). Socio-technical regimes are given a certain degree of durability by the 'rules' which constitute their existence, as well as the fact that they are embedded in institutions and infrastructure (Geels, 2002; 2004). The 'landscape' refers to 
the wider societal background within which the regime and niche are situated and which can bring pressure upon regimes (Smith et al., 2010). A niche reflects the space where a new innovation can deviate from the rule of the dominant regime (Geels, 2004).

The starting point for niche analyses is often a novel technological artefact (Geels, 2004; Raven et al., 2010). Therefore, a key focus of SNM has been on 'radical' and unproven technologies and the niches that support their development. Such niches provide protection from the 'selection environment', normally understood as a market in which the embryonic innovation is initially uncompetitive (Coenen et al, 2010). Protection for novel innovations can take a number of different forms (Rip, 2012). Smith and Raven (2012) outline a number of different dimensions and processes of protection whilst also arguing that a distinction can be made between active and passive forms of shielding, the former reflecting the existence of intentionality created protection. They outline three possible kinds of passive shielding which can provide unmeditated protection for novel experiments: geographic, institutional and cultural. It is argued herein that an alternative milieu actually reflects a convergence of the geographical and cultural dimensions of protection: a form of passive geographical niche which creates certain kinds of sociocultural protection that allow experiments to emerge. Smith and Raven (2012) identify 'socio-cognitive' as one of their six dimensions of protection. They however relate it primarily to the way in which space for creating new knowledge is produced by innovation support and R\&D programmes, whereas this paper adopts a broader understanding.

Within the sustainability transitions literature there has been only limited research into the nature of sub-national geographical niches. Much of this work has focused on the role that cities play in transition processes, particularly in relation to the governance of transitions (Bulkeley et al., 2011; Hodson and Marvin, 2009; 2010; Rohracher and Späth, 2013). Coenen et al. (2010) explore proximity advantages in relation to Dutch Aquifer Energy Storage. Similarly, Raven et al. (2008) stress the geographical contextualisation of niche experiments. A recent review by Hansen and Coenen (this issue) highlights work in 
the field where certain aspects of geographical proximity are important. One area of literature that they highlight argues that informal local institutions are significant in the shaping of transition processes. Whilst an alternative milieu cannot really be considered a local institution, this paper also illustrates the way in which localised cultural norms, values, worldviews and networks can influence innovation processes by creating sociocognitive space for experimentation. Of course, there is a rich body of work in economic geography that has contributed theoretical propositions to explain the uneven geography of innovation, including a number of different Territorial Innovation Models (TIM) which describe how local institutional dynamics shape innovation processes (Moulaert and Sekia, 2003). TIMs have been subject to a number of critiques, in particular for overstating the importance of geographical proximity and understating the significance of non-local interactions (Bunnell and Coe, 2001). Thus, it is argued, that multiple forms of proximity can be significant in innovation processes (Boshma, 2005). This paper does take a position which argues for the significance of geographical proximity but, whilst an alternative milieu is a materialised and situated phenomena, it is also, to some degree relationally produced, connected to other places through networks and flows, which partly drive its (re)production. The concept can therefore be understood as a form of 'moderate relationalism' which treats space both as fixed and fluid (Jones, 2009). In this sense it is a particular kind of 'convergence space' (Routledge, 2003) for multiple and overlapping countercultural practice, networks and institutions.

Another critique of TIMs is that they are generally narrow in their understanding of innovation, conceptualising it as capitalist-based technological development (Moulaert and Sekia, 2003). By contrast, this paper argues that alternative milieu provide protection for at least three different kinds of sustainability experiment. The first is the conventional 'market based' innovation, goods and services that are provided to customers and which could 'scale up' through the expansion of market share. Secondly, there are grassroots innovations. This paper defines these as non-market in nature, forms of sustainability experimentation which emerge from civil society and that involve volunteerism or new 
forms of social organising. A growing body of work has begun to highlight and explore the role that social movements and civil society actors can play in the development of innovations relating to sustainability (Smith, 2012; Davies and Mullin, 2010; Toke, 2011; Hess, 2005, 2007; Truffer, 2003; Lounsbury et al., 2003; Pickerill and Maxey, 2009b). Seyfang and Smith (2007) propose the concept of 'grassroots innovations' to describe the interface between civil society sustainability innovation and the niche theories derived from sustainability transitions. Work in this vein has therefore sought to test the applicability of sustainability transition concepts in the context of grassroots innovations such as community energy and complementary currencies (Heilscher et al., 2013; Seyfang and Longhurst 2013, Longhurst 2012, Seyfang and Haxeltine, 2012). The third type of innovation supported by alternative milieu is conceptual innovation (Vedin, 2007). This reflects experimentation with new kinds of sustainability concepts or ideas that could be 'systemic' in their aspirations or implications (Hegger et al 2007; Monaghan, 2009). This paper argues that an alternative milieu can provide protection for experiments relating all three of these forms of innovation, as described in the next section.

\section{The alternative milieu around Totnes, Devon}

\section{1 alternative milieu}

The concept of an alternative milieu refers to a localised density of countercultural institutions, sub-cultures, practices and businesses (Longhurst, 2013). Specifically in the context of this paper, the milieu emerged from a set of countercultures which gained widespread popularity during the 1960s and 1970s and to some extent have continued, described here using five dimensions (see Table 1 below). The lens of an alternative milieu is therefore an approach to understanding the formation of alternative places, and the socio-economic patterns which unfold at such sites. The concept of an alternative milieu has some resonance with one of the TIMs - the notion of an regional innovative milieu (Crevoisier, 2004). The concept of a regional innovative milieu points to the significance of geographical proximity and interconnectedness of institutions in supporting and protecting new forms of innovation (Maillet, 1995). The concepts have 
some similarity insofar as they are both interested in the effects of a geographically embedded density of actors, networks and institutions. However, the innovative milieu concept is rooted in the new economic geography and reflects a specifically territorial approach to understanding economic development and innovation (Crevoisier, 2004). Applied empirically it can be used to study the milieu that forms around a specific form of innovation, such as lightweight vehicles (Truffer and Dürrenburger, 1997) or micro technologies (Maillet et al, 1995). In contrast, the notion of an alternative milieu is a heuristic that is intended to unpack some of the complexities of countercultural places and to avoid reducing such places to a single defining characteristic of alterity. The actual nature and extent of different dimensions of a milieu will vary from case to case, but many - including the example detailed in this paper - include a density of 'green' practices, cultures and institutions. The existence of an alternative milieu can have a range of effects on a locality, including stimulating in-migration and the the emergence of specific place reputations (e.g. 'hippy', 'new age', 'bohemian' etc.) (Longhurst, 2013). The way in which an alternative milieu supports experimentation is therefore only one aspect of its wider effects on the locality.

Totnes is a small market town in the South West of the UK which is the centre of a well established alternative milieu (Longhurst, 2011). It was selected as an exemplar or 'paradigmatic' case study (Flyvberg, 2001) of grassroots experimentation because it has an established reputation as a site of alternative culture and grassroots innovation. For example, Douthwaite $(1996,349)$ describes it as a 'hotbed of economic experimentation' (see also Dauncey 1986; 1988). The exact nature of the experimentation and its origin and significance was therefore the focus of an extended case study. This involved a strong ethnographic core (the researcher lived in the field for two and a half years) and a range of data collecting strategies including semi-structured interviews, archival work and participatory research. This was a process focussed research methodology (Geels, 2011 see also Langley et al. 2013) which used a narrative sense making strategy (Langley, 1999). 


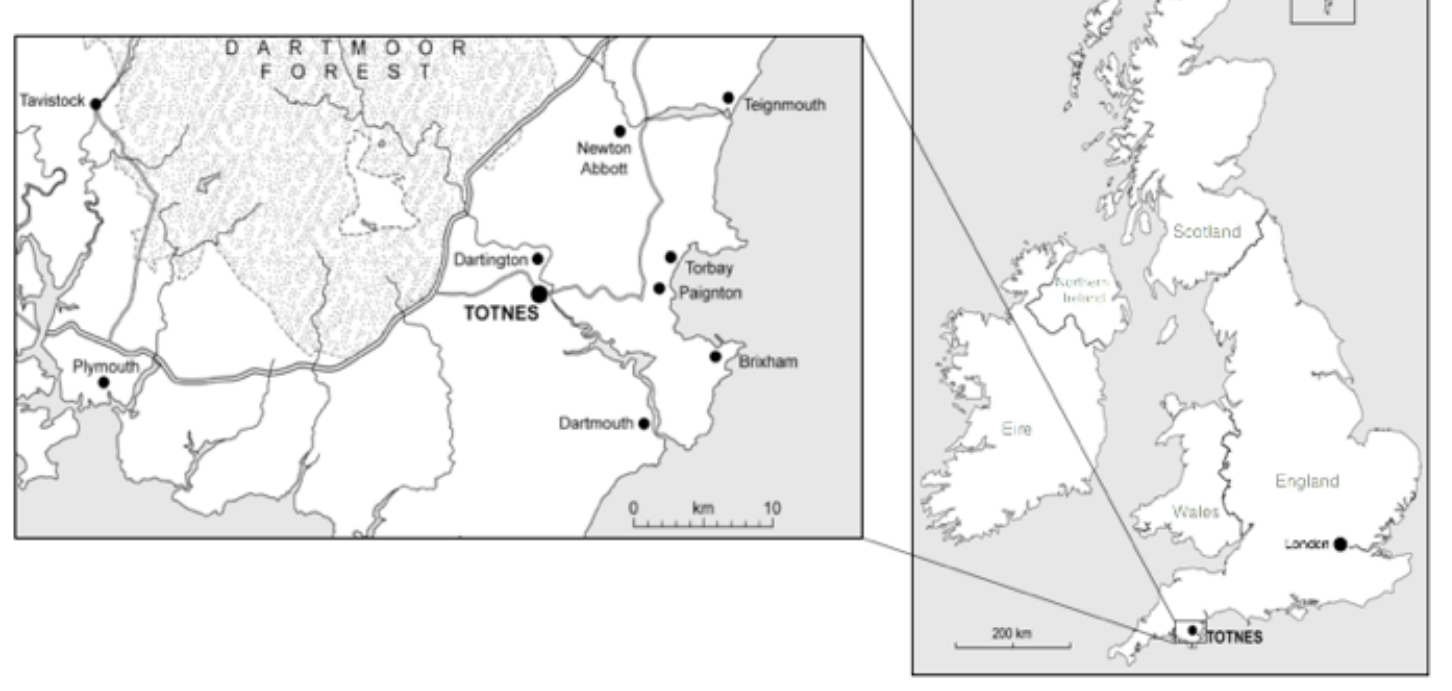

Figure 1: Location of Totnes, Devon

The origins of the alternative milieu in the Totnes locality are rooted in the Dartington experiment, a utopian community established in 1925 by the wealthy American heiress Dorothy Elmhirst and her English husband Leonard (Hardy, 2000). They purchased the Dartington country estate a few miles outside of Totnes and set about establishing it as an experiment in agriculture, progressive education and the arts (Bonham-Carter,1958; Young, 1996) Over several decades Dartington established a considerable range of activities including a boarding school, a cutting edge art college, and various businesses and projects, the extent of which caused a localised milieu to build up around Dartington. The impact of the Dartington community on the locality was fairly limited until the late 1960s and early 1970s when members began experimenting with countercultural ideas both formally within the structures of Dartington's institutions, and informally in the wider public sphere. The effect of this experimentation was a growing proliferation of alternative practices, institutions and organisations. Fuelled by in-migration and a set of growing reputations, the alternative milieu became a self-sustaining phenomenon with 
the town of Totnes as its symbolic and economic capital (Longhurst, 2013). The key dimensions of the Totnes milieu are summarised in Table 1.

\section{Table 1: Five dimensions of an alternative milieu}

\begin{tabular}{|c|c|c|}
\hline Strand & Details & Examples in Totnes alternative milieu \\
\hline $\begin{array}{l}\text { Radical } \\
\text { politics }\end{array}$ & $\begin{array}{l}\text { Organised political movements and parties } \\
\text { that seek to radically change wider social } \\
\text { and political systems (e.g. see Esler, 1971; } \\
\text { Harman, 1998). }\end{array}$ & $\begin{array}{l}\text { The Green party contested four general } \\
\text { elections between } 1983 \text { and } 1997 .\end{array}$ \\
\hline $\begin{array}{l}\text { New social } \\
\text { movements }\end{array}$ & $\begin{array}{l}\text { Issue based movements that seek social } \\
\text { change through engagement in contentious } \\
\text { politics (e.g. see Buechler, 2000; Watts, } \\
\text { 2001). }\end{array}$ & $\begin{array}{l}\text { Environmentalism, feminism, peace activism } \\
\text { and conspiracy politics all have a strong } \\
\text { presence in the area. }\end{array}$ \\
\hline $\begin{array}{l}\text { Alternative } \\
\text { Pathways }\end{array}$ & $\begin{array}{l}\text { The mixing of social change goals with } \\
\text { other goals, in particular in the building of } \\
\text { new alternative institutions e.g. organic } \\
\text { food, alternative education (e.g. see Hess, } \\
\text { 2007). }\end{array}$ & $\begin{array}{l}\text { Strong organic food 'countercuisine'. } \\
\text { Established alternative heath sector. Several } \\
\text { alternative schools. Established site of } \\
\text { alternative press both local and national. Local } \\
\text { economic experiments such as local loan funds } \\
\text { and local currencies. }\end{array}$ \\
\hline $\begin{array}{l}\text { Alternative } \\
\text { Spiritualities }\end{array}$ & $\begin{array}{l}\text { Non-traditional spiritual practices, such as } \\
\text { those 'imported' from the East, and others } \\
\text { associated with the 'New Age' (see Heelas, } \\
\text { 1996; Kemp, 2004). }\end{array}$ & $\begin{array}{l}\text { Western Buddhism, Anthroposophy and } \\
\text { Quakerism all strong in the area. Several other } \\
\text { examples of alternative spiritual practices also } \\
\text { present. }\end{array}$ \\
\hline $\begin{array}{l}\text { Alternative } \\
\text { Lifestyles }\end{array}$ & $\begin{array}{l}\text { Non-conventional lifestyles that are chosen } \\
\text { specifically as alternative to mainstream } \\
\text { lifestyles e.g. back to the land, communal } \\
\text { living etc. (e.g. Halfacree, 2006; McKay, } \\
\text { 1996). }\end{array}$ & $\begin{array}{l}\text { Strong connections to the traveller and festival } \\
\text { scenes. Numerous examples of people living in } \\
\text { unconventional ways e.g. intentional } \\
\text { communities, back to the land, low impact etc. } \\
\text { Strong local presence of small / ethical / } \\
\text { lifestyle businesses. }\end{array}$ \\
\hline
\end{tabular}

Conceptualising an alternative milieu through multiple strands provides a useful heuristic for revealing the full breadth of countercultural activity within a given locality. However, in practice there is significant overlap and intersection between different activities, groups and practices. The exact patterning of overlap between these different networks cannot not be confirmed without more detailed empirical network analysis. However, some broad intersections can be observed. For example, as noted above, there is a strong localised organic 'countercusine' stretching back to the 1970s and consisting of producers, processors and localised demand (Ilbery et al. 2006, Transition Town Totnes, 
2008, CPRE 2010). This is not created by a single alternative culture but by the overlapping propinquity of a range of different sub-countercultures. As well as the 'green' cultures in the area, the density of Complementary and Alternative Medicine activity in the area (c.f Andrews, 2003) and some specific spiritual/cultural movements such as anthroposophy also play an important factor in supporting localised organic demand and production. In other words, the organic countercuisine is supported by a number of overlapping localised subcultures. Key social entrepreneurs also play a role in linking groups and networks acting as the catalysts for projects before moving on to establish new ventures (Longhurst, 2011).

\subsection{Sustainability experimentation}

In recent decades there have been various experiments across the different dimensions of the alternative milieu around Totnes. This section highlights three particular examples of sustainability experiments which can be considered as exemplars in terms of their significance, and which relate to the three categories outlined in section two. This claim of significance has three dimensions. Firstly, it is based on the argument that the experiment was in some sense pioneering in the UK context. These were early examples of ideas which have become much more widespread. Secondly, in many cases, those involved in the local experiments actually played a critical role in seeding further experiments, in the spread of ideas or practices. Thirdly, in two of the cases the significance comes with the size of the experiment. Like may common categories 'experiment' can be a somewhat slippery term. Here then, it is simply used to denote a process of experimentation with some kind of novelty. Each of these different kinds of innovation is now exemplified with an example from the Totnes milieu.

\subsubsection{Grassroots: Totnes 'Acorn' LETS}

In 1986 Totnes became one of the first places in the UK to establish a Local Exchange Trading Schemes (LETS) a form of grassroots currency system. LETS had originally been developed in Commox Valley, Canada in 1983 as a tool to facilitate economic activity 
within a locally depressed economy. A LETS system functions as a mutual credit system whereby members can exchange services (and sometimes goods) with transactions centrally recorded. The system effectively permits users to create a form of money amongst themselves. Within the UK, LETS became associated with 'DIY culture'1 a kind of 1990s counterculture involving green activism, music and direct action (see McKay, 1998) where it was often associated with attempts to build a parallel anti-capitalist economy (Bowring, 1998). The first official LETS in the UK is normally cited as Norwich, in 1985, but a system - in which the currency was named the Acorn - was also launched in Totnes at around the same time. Although this first system struggled, activists from Totnes played an important role in popularising LETS in the UK, for example, through Guy Dauncey's (1988) book After the Crash (Croall, 1997). Other local activists developed important software that helped with the computerisation of systems. A second system was launched in the 1990s became one of the largest rural schemes in the UK (Williams, 1995). LETS organisers from this phase also played an important role in 'exporting' the idea to France in 1994 when Richard Knight from the Totnes LETS system gave a lecture in the South of France (SEL Terre, 2004). In the 2000s, along with a lot of other UK systems, the Totnes Acorn entered a decline, struggling for resources and members.

\subsubsection{Market based: Riverford Farm}

A key domain of experimentation has been with alternative food systems. In the 1970s Dartington had established a school for self-sufficiency, and as far back as 1979 the South Devon Organic Growers co-op was established, modelled on Swiss Community Supported Agriculture (CSA) schemes. CSA involves attempts at building alternative food systems and this was a very early example of experimentation with CSA in the UK over 10 years before CSA is generally regarded to have reached the UK. This collective continued into the mid 1980s, and, in part influenced by these pioneering growers, Guy Watson began growing organic vegetables on his father's Riverford farm in 1985. The ethics of his

\footnotetext{
1 'DIY' stands for 'Do It Yourself'. Whilst in common English it refers to domestic repairs and maintenance, DIY Culture refers to grassroots politics and social action, often incorporating underground artistic or creative activities.
} 
business were also influenced by other local activists, and, in particular, a book called Honest Business (Phillips and Rasberry, 1981)² which espoused the ideas of a 'right livelihood'. Other local producers continued to experiment with novel delivery systems and in around 1992, he began a vegetable box delivery scheme. This has incorporated two particular aspects of social innovation which has enabled it to become one of the largest vegetable box schemes in the UK (Clarke et al., 2008). Firstly, a franchised delivery operation has enabled significant geographical expansion. Secondly, in order to provide organic produce it has developed regional farm hubs in partnership with other farms in order to shorten distribution networks outside of the South West of the UK. The Riverford operation in Devon is also supplied by the South Devon Organic Growers co-operative which was established by Watson in order to supply the box scheme. Both Watson and the Riverford business have won several awards for sustainability.

\subsubsection{Conceptual innovation: Permaculture}

Permaculture is an ecological design approach to sustainability, often, but not exclusively with a focus on agricultural production (Mollison, 1997). It was first developed in Australia in the late 1970s by Bill Mollison and David Holmgren and has been a growing movement since then. Totnes became a site of permaculture experimentation in 1986 after a group of local people travelled to the South of France for a permaculture design course. Subsequently, the embryonic Permaculture Association of the UK was relocated to South Devon and regular courses were started on a piece of rented land which also functioned as a 'low impact' community. This led to significant new energy being committed to the development of permaculture in the UK and several prominent members of the UK permaculture movement did their training there including Whitfield (2000) and Bell (2004). In 1992 a separate project, the Agroforesty Research Trust, was established on the

\footnotetext{
${ }^{2}$ In terms of links to other countercultural places the Phillips and Raspberry book is an illustrative example. Dartington had forged some connections with projects in San Francisco, USA and Michael Phillips visited Dartington in 1979 to speak about the pioneering Briarpatch small business network which had close links to the Whole Earth Catalogue (see Briarpatch, 2013). Off the back of this visit a south-west UK version of Briarpatch was established, although it did not last for long. Furthermore, one of Dartington's businesses, Dartington Farm Foods, appears in Honest Business as a case study.
} 
Dartington estate to experiment with permaculture techniques and continues to be a prominent site of permaculture experimentation, in particular temperate agroforestry. ${ }^{3}$ The permaculture philosophy has also been influential within other local experiments including a Green Community Office which supported the 1990s LETS scheme, the Transition Town movement which was launched in Totnes in 2006 by permaculture teacher Rob Hopkins (Hopkins 2008), and the Landmatters low impact community who are attempting to develop viable self-sufficient lifestyles. ${ }^{4}$ Indeed, the Transition Town movement has been responsible for considerable amounts of grassroots and conceptual innovation around ideas of community led 'energy descent', both locally and beyond. Table 2 summarises the three exemplars.

\section{Table 2: Exemplars of sustainability experimentation in Totnes area.}

\begin{tabular}{|c|c|c|c|c|}
\hline $\begin{array}{l}\text { Type of } \\
\text { experiment }\end{array}$ & Example & $\begin{array}{l}\text { Nature of } \\
\text { experiment }\end{array}$ & Duration & Significance \\
\hline Grassroots & LETS & $\begin{array}{l}\text { Local currency } \\
\text { scheme. }\end{array}$ & $\begin{array}{l}1986- \\
\text { c2005 }\end{array}$ & $\begin{array}{l}\text { - Pioneering in UK context } \\
\text { - Local activists important in regional, } \\
\text { UK and French diffusion. } \\
\text { - One of largest rural LETS schemes } \\
\text { in UK (mid 1990s) }\end{array}$ \\
\hline Market & $\begin{array}{l}\text { Riverford } \\
\text { Organics }\end{array}$ & $\begin{array}{l}\text { Organic box } \\
\text { delivery system } \\
\text { incorporating } \\
\text { producer co-op, } \\
\text { regional hubs } \\
\text { and franchise } \\
\text { model. }\end{array}$ & $\begin{array}{l}1992 \\
\text { onwards }\end{array}$ & $\begin{array}{l}\text { - Pioneering in UK context } \\
\text { - One of largest organic vegetable } \\
\text { box schemes in UK } \\
\text { - Model of sustainable agriculture }\end{array}$ \\
\hline Conceptual & Permaculture & $\begin{array}{l}\text { Experiments } \\
\text { and learning } \\
\text { involving novel } \\
\text { sustainability } \\
\text { concept. }\end{array}$ & $\begin{array}{l}1986 \\
\text { onwards }\end{array}$ & $\begin{array}{l}\text { - Pioneering in UK context } \\
\text { - Local projects instrumental in } \\
\text { development of permaculture in UK } \\
\text { - Influence on other local projects } \\
\text { and initiatives }\end{array}$ \\
\hline
\end{tabular}

\footnotetext{
${ }^{3}$ For further information see http://www.agroforestry.co.uk/ last accessed 23/09/14

${ }^{4}$ For further information see http://landmatters.org.uk/ last accessed 23/09/14
} 


\section{Alternative milieu and socio-cognitive space for sustainability innovation}

At one level, it might be taken as self-evident that a locality that contains a density of green-related sub-cultures and groups might produce a number of sustainability experiments. However, this paper argues that it is that it is not simply the density of 'green' activities which is significant in creating protective space, but that it is also produced by the cumulative effect the wider alternative milieu. This section outlines three different ways in which the milieu creates socio-cognitive space for experimentation. The first relates to the way in which it produces ontological and epistemological multiplicity, creating space for new ideas to emerge. Secondly, is the way in which it produces spatial imaginaries which support the idea that it is a good place for experimentation with alternatives. Thirdly is the way in which it provides ontological security for those involved in alternative practices - giving them the confidence to experiment.

\subsection{Ontological and epistemological multiplicity}

The first dimension of socio-cognitive space produced by the alternative milieu reflects the way in which it provides a form of space for radical ideas to be enacted. Goffman and Joy (2005) suggest that the history of countercultures is also the history of 'free thinking'. Several interviewees spoke of the way that their particular area of practice was perceived to be 'cranky' when they first started out but that there was an openness to such ideas within the locality. This openness was regarded as an important factor in explaining why Totnes has become a site of experimentation across a range of different areas. According to one local business owner it is a place that is

willing to give slightly alternative, slightly off the wall kind of ideas an opportunity or chance...the community has a history of trying new things out 
One explanation for this openness to new or 'cranky' ideas is that many such ideas have circulated locally for some time, a factor that breeds tolerance amongst the wider community. At a most basic level the existence of various green worldviews means that there is space for new ideas that fit within the purview of those particular realities. For example, Rob Hopkins suggested that by picking Totnes to develop his Transition Town community initiative he was

delivering a message about peak oil and climate change and a need to respond to people who are already more open to those kind of ideas.

Interview with Rob Hopkins, co-founder of Transition Town Totnes

Therefore one way of considering the Totnes alternative milieu is as a site of multiple 'bounded rationalities' (Wilk, 1996) as opposed to simply a site of 'irrationality'. An individual's behaviour is 'rational' from the perspective of their own subjective worldview. Thus, those who believe that we are on the brink of global 'resource depletion' are more likely to find ideas of economic localisation posited by the Transition Town movement as a potentially rational response. Here then, the participants in the initiative find the innovation's problem framing credible and convincing (Longhurst, 2012). Therefore, it is not surprising that a density of overlapping green networks and cultures is likely to be supportive of different kinds of sustainability innovation. However, there is another important factor that creates socio-cognitive space which relates to the full diversity and breadth of unconventional thought. Some strands of the milieu actively reject scientific and rationalist modes of thought and are based on alternative epistemologies. This 'antiscientific' tendency is often the focus of negative depictions of countercultural practices and places:

The south-west is the undisputed capital of British credulousness. In Totnes, Glastonbury and numerous other mumbo jumbo-drenched towns throughout the region, pseudo-druids and new agers shamble between homeopathic "clinics" and crystal emporia, seeking to cure their manifest problems with treatments so magical that their effects are scientifically undetectable. Totnes, in particular, has a distinguished history of mass charlatanry, largely thanks to its Leechwell springs, 
which were reputed in the middle ages to banish leprosy. Even in 2003, "a rare triangular healing pool" was reportedly discovered behind Leechwell Lane.

Benedictus $(2007,4)$

In contrast to this perspective, it is arguable that this culture of 'credulousness' is actually an important factor in creating the socio-cognitive protection for new forms of sustainability experiment. In other words, it creates the socio-cognitive space for experiments to emerge by stretching the socially accepted (and constructed) boundaries of possibility. An alternative milieu therefore consists of a range of different epistemologies and ontologies, from different spiritual practices, to new age beliefs, to radical politics, to - in the case of Totnes - complexity science. ${ }^{5}$ The fact that people are willing to believe all sorts of things are possible underpins social experimentation, supporting the argument that alternative epistemologies are a significant aspect of opening up new experimental possibilities (Starr, 2000, 154). Furthermore, this epistemological diversity creates ontological diversity, constituting the milieu as a site of multiple, co-existing and neighbouring epistemes (Law and Mol, 2006). This multiplicity stretches the realms of the possible, creating space for new unconventional ideas to emerge. An important local activist certainly felt that this cumulative effect of epistemological and ontological variety was was significant in creating the space for new ideas:

and so that's sort of opened a space for that sort of thinking in Totnes. So, you know, there was always...somebody like me...l can be thinking....radical things and I wasn't considered too weird because there were a lot more weirder people than me hanging around because of Dartington Hall, you know.

Interview with former community activist B

\footnotetext{
${ }^{5}$ See Thrift (1999) for discussion of geographies of complexity science which includes the work of Schumacher College, based on the Dartington estate (see also Phillips 2008).
} 
In other words, the breadth of radical ideas and unconventional belief systems creates the space for still further new ideas to be articulated.

\subsection{Spatial imaginaries}

The second important dimension of socio-cognitive space relates to how individuals believe that the area is a good place for experimentation. The argument here, is that the way a place is conceived can effect the actions of the inhabitants (Wolford, 2004). Thus, there are a number of spatial imaginaries which support sustainability innovation, in particular, a utopian reading of the physical landscape appears to stimulate experimentalism. Whilst the visually attractive landscape has acted as a significant migratory driver for the milieu, it has also acted as a source of inspiration. As one local activist put it:

It's such a lovely environment. You know, it's like living in a fairytale. Just the landscape, Dartington, the Dart, its just its 'Ow, the world can be better!' The landscape gives you that kind of feeling, a breath of fresh air, it can be contained... Totnes is a nice contained little package, but with open views of the Dart and Dartmoor and all these lovely things.

Interview with former community activist $A$

The psychologist Czikszentmihalyi (1996) has suggested that beautiful environments can stimulate new connections amongst ideas and new perspectives on issues. As well as the importance of the inspirational 'readings' of the natural landscape, interpretations of the 'beauty' of Totnes were also seen as important by some, the townscape having its own utopian aesthetic. A predominance of smaller retailers gives it a particular sense of place, and one that is in keeping with 'small is beautiful' strands of ecological thought (e.g. Schumacher, 1973; Shuman, 2000). Several interviewees mentioned the 'inspirational' aesthetic quality of Totnes and the wider area. Furthermore, the local visibility of 'alternative' practices and cultures also feeds the imaginary that the area is a site of possibility: 
And then there's everywhere around, there's alternative things actually happening as well. Dartington is there and happens. Sharpham ${ }^{6}$ is there and happens. The Totnes Natural Health Centre...the other one in the High Street, you know?...Conker Shoes, all these things...There are these businesses. There are alternative projects, 'alternative' in inverted commas, but there are projects happening, so the social infrastructure also gives that message, as something can happen here. You take your kids to the school and people are discussing projects and futures and different social, environmental, economic infrastructure. So one is getting those ideas reinforced which if you are in the middle of a big city, it's much harder to find that, all those elements supporting the internal vision. It's like "Ah, I can do something"

Interview with former community activist $A$

This visibility of practices and experiments reinforces the imaginary of Totnes as a 'good place' for these sorts of experiment, which in turn attracts new experiments, as explained by Rob Hopkins relating why he chose Totnes as the site to develop his Transition Town model:

You know I could have gone to Hull and spent 15 years trying to get it working or actually here in the sense there are certain towns like Stroud, Lewes, Totnes all the places that actually became transition places first that have a long history of being kind of laboratory towns, laboratory places for innovative ideas...my wife had lived here some years previously so she knew some people here and yeah so it felt like it was somewhere where the transition idea could embed fasters than it could in other places

Interview with Rob Hopkins, co-founder of Transition Town Totnes

More radical forms of spatial imaginary are associated with some localised countercultural epistemologies, in particular as those associated with various kinds of 'earth mysteries' such as ley lines (Michell, 1983). Advocates of these perspectives argue that the presence

\footnotetext{
${ }^{6}$ The Sharpham Estate was owned by the former chair of the Dartington Trust, and son of the founders, Maurice Ash. From the 1980s onwards he developed a number of activities on the site including a Buddhist community, agricultural small holdings and artisan food production.
} 
of particular 'earth energies' is the reason that certain practices have flourished in the area. Richard Smith, a key figure in the local anthroposophical community until his recent death was an important figure in articulating such discourses. For example, he suggests that in the Totnes area a

wealth of activities; healers and therapists, artists, craftsmen, educators and musicians abound... One can begin to see how the Totnes - Dartington area is fed by the pure waters off the hills as well as the mighty surges from the sea. In this area that we call the heart sphere of the landscape much has already arisen and much can still arise.

Smith and Cooper $(2006,8)$

Smith builds his case on the legend of Brutus of Troy who, according to Geoffrey of Monmouth's Historia Britonum landed at Totnes to found Great Britain, a popular local myth which is used to reinforce the idea that it is a 'special' place. Such lay narratives therefore shape local spatial imaginaries. The argument being made here is that these lay narratives should be taken seriously because, for some people, they underpin the belief that the Totnes area is a 'special' place where things can happen and which encourages experimentation.

\subsection{Ontological security}

Due to the geographical propinquity of a number of different spiritual and educational institutions that deal with different approaches to personal transformation, the Totnes area developed a reputation as a liminal site: a 'node' on the global 'spiritual trail'. Liminality is related to processes of individual change, of openness to new ideas and of 'seeing' the world in different ways, and has been associated with some countercultural practices and sites (e.g. Shields, 1991). Many of the countercultural strands discussed featured in Table 1 above involve processes aimed at 'raising' or transforming consciousness (e.g. feminist / ecological / spiritual). This means there is a density of people within the local milieu who are themselves open not only to 'alternative' ideas but 
also to the processes of personal transformation that enables them to 'see' the world differently. This disposition is sometimes reflected in the term 'seekers', which is often associated with the 'New Age' (Button and Bloom, 1992). A former activist describes how Totnes creates a supportive environment for such transformations:

...just a supportive symbol in a sense for "Yes, I'm changing, I can change". I don't know what it is, but it's to do with all of these things and lots of people come here and their relationships change, their work changes. It's a supportive environment to enable them to look at themselves a bit in whichever area. So those are the kind of belief systems and then there are the resources around to facilitate those kinds of changes.

Interview with former community activist $A$

The fact that many of the innovators were also involved in other 'self-transforming' practices, suggests that self-transformation might be a significant part of the innovation process. This resonates with Mihaly Czikszentmihalyi's (1996) argument, that certain 'creative environments' provide a density of interactions and effervescence of ideas that prompts the experimentally inclined to experiment more readily than in more conservative or repressed settings. One way of understanding this is that such environments provide the necessary ontological security for experimentation. For example, the density of the local milieu means that there are people who are interested in new green ideas and projects and are willing to support new initiatives:

I mean there's a concentration of people who open at one level again to proposals of this nature where do you find easily bankers, estate agents and accountants who would be interested in these things? People come for the Steiner School or they come to Dartington or they come for whatever and as they sort of sit in Totnes, they become influenced if they are in some of those environments, they become influenced by others and they are open. So at the first level, people will come along to a meeting and they will join in, so its easier in Totnes to launch some of these things. 
Volunteers and supporters provide not only practical resources, but moral support which appears to give pioneers the courage to face challenges. As one pioneering organic farmer suggested:

So I'm sure it helps because if you're struggling and you're in an area that is supportive, that's one thing but if you're struggling in an area where they all think you're wasting you time then it gets to you.

Interview with organic smallholder

Localised groups and networks appear to reinforce the 'ontological security' of members by providing a shared sense of self-identity and worldview. The existence of shared cognitive frames ('like-mindedness') is essential for determining what makes a given behaviour 'appropriate' or 'acceptable' (Giddens, 1991, 36). For example, speaking of their decision to live 'illegally' on their land, one interviewee suggested that:

...round here people think it is cool so it's easier, it's easier to sort of think 'Yeah we're OK' you know? We're not mad!

Back to the land dweller \& organic smallholder

Thus ontological security also contributes to the normalisation of certain practices and forms of (liminal) experimentation such as living outside the conventional housing system. One way of conceptualising how an alternative milieu supports innovation is therefore as a 'naturally' occurring form of skunkworks. Skunkworks are

small and often subversive units within a larger organisation that are created in order to pioneer the development of a technological innovation.

Rogers $(2003,149)$

They create space for innovation because the members are able to escape routinised, organisational procedures and social norms. Thus there are obvious parallels with how 
countercultural sites can create the space for individuals to escape the dominant, 'taken for granted' norms and cognitive frames, particularly as those are within countercultural networks are often also able to occupy 'free space' because they are less structured by work relations and lifestyle constraints, enabling them to dedicate time to grassroots projects and activities (McAdam,1986).

\section{Conclusions}

A central purpose of this paper has been to draw attention to how 'alternative' places can protect the development of sustainability innovations. Following in the tradition of recent theory relating to sustainability transitions it has used the metaphor of a protective niche to explain how the density of a localised alternative milieu creates a form of passive protection for sustainability innovations and experiments. More specifically, it has described how the milieu creates specific forms of socio-cognitive protection that support the emergence of experiments and get further translated into different forms of support, such as economic and practical. In this way the paper makes a contribution to the geography of sustainability transitions, by drawing attention to the hitherto unrecognised relationship between alternative places and sustainability innovation. It has also further developed the notion of socio-cognitive space, illustrating how multiple dimensions of this can support experimentation with novelties. In terms of the significance of these kinds of geographical niches, the paper has evidenced that certain kinds of innovation can be productively supported in such localities. Whilst it has illustrated that there is some diversity in the form of innovation, it is unlikely that it is going to take the form of highly capital intensive or techno-science driven technology. However, it is arguable that these spaces are still significant, particularly because of the opportunity they offer to experiment with new concepts and ideas, something which it has been argued is a critical part of sustainability transitions (Hegger et al., 2007; Monaghan, 2009). 
An important question relates to the wider significance and applicability of this particular case. Hansen and Coenen (this issue) note that a weakness of geographical analyses is often a focus on highly idiosyncratic case studies of specific regions and localities. This is a valid concern, and it suggests a need for further work on the relationship between countercultural place and innovation, both in terms of other places and other forms of innovation. The exceptionalism of the Totnes milieu will only be established through such work. However, there are some indications that this might be a worthwhile endeavour. Kockel (1999) links countercultural incomers with different forms of entrepreneurship and innovation in Western Ireland. The San Francisco bay area has a complex and long established alternative milieu (c.f. Castells, 1983). There is evidence that the alternative milieu around San Francisco had connections to the emergence of both biotechnology (Vettel, 2006) and home computing (Turner, 2006). In the latter case, the geographical proximity of institutions such as the Whole Earth Catalogue and the Stanford Research Institute appear to have been a significant factor. Florida's (2002) work also makes a link between 'bohemianism' and geographies of innovation, arguing that the presence of a significant bohemian concentration correlates with an underlying openness to innovation and creativity within a locality. Yet, it is important to note that localities with dense alternative milieu are relatively unusual and the result of specific set of processes. Within the UK there are only a handful of towns and (areas of) cities which appear to have a similar densities of countercultural networks and institutions. It is doubtful that an alternative milieu could be created purposively, particularly as many have their roots in the 1960s and 1970s or even earlier. However, those interested in creating experimental spaces of any kind, might want to attend to the socio-cognitive conditions described in this paper, particularly expanding the 'belief space' and supporting the ontological security of experimenters.

The co-existence and visibility of the independent and 'alternative' shops, Alternative Food Initiatives, organic growers, community enterprises and NGOs around Totnes is unusual and reinforces the 'place myth' of its role as a vibrant centre where alternative 
futures can be enacted. As discussed above, these also contribute to countercultural 'sense(s) of place' which encourage further innovation and experimentation. However, to some extent this is an illusion, and whilst the milieu creates the space for experiments, it may not make them any more viable in the longer term (Longhurst, 2011). Thus small scale organic production is not necessarily any more economically viable in the Totnes locality than elsewhere. Caution must therefore be exercised in holding up such places as examples of sustainability futures (e.g. Siegle, 2011; BBC, 2009) or making claims that initiatives can be easily replicated elsewhere. Despite the overlaps that exist between different networks, it should also be noted that there is often socio-cultural conflict both within and towards the alternative milieu (Longhurst, 2011). The in-migration that sustains alternative milieu can be a source of conflict between those who consider themselves to be 'local' and more recent incomers (e.g. Barker, 2012). It can also contribute to the processes of gentrification of alternative places that occurs as their reputation grows (Ley, 1996; Barker, 2012; Smith and Phillips, 2001). Some residents can also object to the various place images that become associated with such places and feel 'invaded' by the alternativeness. However, there is also conflict within the milieu, between different strands of countercultural practice. Indeed, it seems that some of the very conditions which create the socio-cognitive space for the emergence of radical or unusual ideas also create the potential for conflict between different perspectives, potentially undermining their potential to grow at a local level (Longhurst 2011).

One feature of the alternative milieu described in this paper is the way in which certain institutions and actors (such as Dartington) connect the Totnes area to a range of other geographically distant places. To some extent the milieu is created by these relational effects, particularly reputations, networks and flows of movement and migration. Such connections create relational 'social movement space' (Nicholls, 2009) through which innovations and ideas have travelled before being recontextualized within the locality. The area can therefore be characterised not simply as a site of experimentation, but also of translation reflecting the way in which concepts evolve they move through space and 
time (Czarniawska and Sevon 2005). For example, none of the cases detailed in section 3.2 actually originated in the Totnes area. The idea travelled to the locality and then - as a site of early adoption - it provided a particularly fertile space for examples of that particular innovation to be developed, which then also stimulated further diffusion and experimentation. Perhaps the most striking recent example of this in the Totnes case is the Transition Town movement which has grown extensively since its launch in 2006. Not only has the 'transition town' concept itself travelled significantly (Seyfang and Haxeltine, 2012) but so too have some of the of the experiments that it has supported, such as garden-sharing and Transition currencies (Longhurst, 2011). This paper therefore makes a first tentative step towards exploring the geographies of grassroots innovation, a topic that has received little attention to date.

There is also considerable scope for exploring other 'alternative' sites and spaces of innovation. Whilst the notion of an alternative milieu is a useful concept for understanding the countercultural dimensions of a particular locality there are other alternative places which function as loci of innovation. For example, hackerspaces (moilanen, 2012), community based digital fabrication labs (fab labs) (Heilscher and Smith, 2014), autonomous social centres (Hodkinson and Chatterton, 2006), low impact developments (Pickerill and Maxey, 2009a) and ecovillages (Avelino and Kunze, 2009). Indeed, the example of Dartington itself in this particular case illustrates the role that intentional communities can have in nurturing new innovation. Thus Coates $(2001,303)$ draws attention to a number of social innovations that have originated in UK utopian communities, such as social work and the Town and County Planning System. Further work on the significance and functioning of such sites and spaces would begin to develop an 'alternative' geography of innovation to that represented by the conventional, market focused territorial innovation models. 


\section{Acknowledgements}

I am indebted to the University of Liverpool for supporting the empirical research on which this paper is based. The paper has also benefited from the support of the Realising Transition Pathways project, funded by the UK Engineering and Physical Sciences Research Council (EPSRC) [Grant EP/K005316/1], and the Transformative Social Innovation Theory (TRANSIT) project [Funded under the EU's 7th Framework Programme, grant agreement 613169]. Thanks to Tom Hargreaves, the reviewers and the editor for their helpful advice on improving the paper. Any outstanding errors are the responsibility of the author.

\section{References}

Andrews, G., 2003. Placing the consumption of private complementary medicine: everyday geographies of older peoples' use, Health \& Place 9, 337 - 49.

Avelino, F., Kunze, I., 2009. Exploring the Transition Potential of the Ecovillage movement European Conference on Sustainability Transitions, Amsterdam, the Netherlands.

Barker, P., 2012. Hebden Bridge: A sense of belonging Frances Lincoln London.

BBC, 2009. Totnes: taking change into their own hands, http://www.open.edu/openlearn/body-mind/totnes-taking-change-their-own-hands Last accessed 23/09/2014.

Bell, G., 2004. The Permaculture Way: Practical Steps to Create a Self-Sustainable World Permanent Publications East Meon.

Benedictus, L., 2007. Way out West, The Guardian. http://www.guardian.co.uk/theguardian/2007/jan/03/features11.g2 Last accessed 23/09/2014.

Bonham-Carter, V., 1958. Dartington Hall: The History of an Experiment. Phoenix House Ltd, London.

Boschma, R., 2005. Proximity and Innovation: A Critical Review Regional Studies 39, 61 74.

Bowring, F., 1998. LETS: an eco-socialist alternative?, New Left Review, 91 - 111.

Briarpatch, 2013. History of the Briarpatch Network aka The Briarpatch Society aka the Briarpatch.http://www.briarpatch.net/ last accessed 23/09/2014

Bridge, G., Bouzarovski, S., Bradshaw, M., Eyre, N., 2013. Geographies of energy transition: Space, place and the low-carbon economy, Energy Policy 53, 331 - 40. 
Buechler, S. M., 2000. Social Movements in Advanced Capitalism Oxford University Press, Oxford.

Bulkelely, H., Castán Broto V, Hodson M. and Marvin S. (Eds) 2011. Cities and Low Carbon Transitions. Routledge, London.

Bunnell, T. G., and Coe, N. M., (2001) Spaces and scales of innovation Progress in Human Geography 25, 569 - 89.

Button, J., and Bloom, W., (Eds) (1992) The Seeker's Guide: A New Age Resource Book The Aquarian Press, London.

Castells, M., 1983. The City and the Grassroots. Edward Arnold, London.

Clarke, N., Cloke, P., Barnett, C., and Malpass, A., 2008. The spaces and ethics of organic food, Journal of Rural Studies 24, 219 - 30.

Coates, C., 2001. Utopia Britannica: British Utopian Experiments: 1325 - 1945, D\&D Publications, London.

Coenen, L., Benneworth, P., Truffer, B., 2012. Toward a spatial perspective on sustainability transitions, Research Policy 41, 968 - 79.

Coenen, L., Raven, R., Verbong, G. 2010. Local niche experimentation in energy transitions: a theoretical and empirical exploration of proximity advantages and disadvantages, Technology in Society 32, 295 - 302.

Coenen, L., Truffer, B. 2012. Places and Spaces of Sustainability

Transitions: Geographical Contributions to an Emerging Research and Policy Field, European Planning Studies 20, 367 - 74.

CPRE, 2010. From field to fork: Totnes. Campaign to Protect Rural England, London.

Crevoisier, O., 2004, The Innovative Milieus Approach: Towards a Territorialized Understanding of the Economy?, Economic Geography, 80, 367 - 379.

Croall, J., 1997. LETS ACT LOCALLY: The growth of the Local Exchange Trading System. Caloustie Gulbenkian Foundation, London.

Csikszentmihalyi, M., 1997. Creativity. Harper Perennial, New York.

Czarniawska, B., Sevón, G., 2005. Translation in a Vehicle, Imitation its Motor, and Fashion Sits at the Wheel, in Czarniawska, B. and Sevón G. (Eds) Global Ideas: How Ideas, Objects and Practices Travel in the Global Economy. Liber and Copenhagen Business School Press Malmö.

Dauncey, G., 1986. A new local economic order, in EKINS P. (Ed) The Living Economy, pp. 264 - 72. Routledge, London.

Dauncey, G., 1988. After the Crash. Merlin Press, London.

Davies, A., Mullin, S., 2010. Greening the economy: interrogating sustainable innovations beyond the mainstream Journal of Economic Geography 11, 793 - 816.

Douthwaite, R., 1996. Short Circuit. Lilliput Press, Dublin. 
Esler, A., 1971. Bombs, Beards and Barricades. Stein and Day, New York

Florida, R., 2002. Bohemia and economic geography, Journal of Economic Geography 2, $55-71$.

Flyvberg, B., 2001. Making Social Science Matter, Cambridge University Press, Cambridge.

Geels, F. W., 2002. Technology transitions as evolutionary reconfiguration processes: a multi-level perspective and a case study, Research Policy 28, 469 - 88.

Geels, F. W., 2004. From sectoral systems of innovation to socio-technical systems. Insights about dynamics and change from sociology and institutional theory, Research Policy 33, $897-920$.

Geels, F. W., 2011. The multi-level perspective on sustainability transitions: Responses to seven criticisms, Environmental Innovation and Societal Transitions 1, 24 - 40.

Giddens, A., 1991. Modernity and Self-Identity. Polity, Cambridge.

Goffman, K., and Joy, D. 2005. Counterculture through the ages: From Abraham to Acid House. Villlard, New York.

Grin, J., Rotmans, J., Schot J., (Eds) 2010. Transitions to Sustainable Development. New Directions in the study of long term transformative change Routledge London.

Halfacree, K., 2006. From dropping out to leading on? British counter-cultural back-tothe-land in a changing rurality, Progress in Human Geography 30, 309 - 36.

Hansen, T., Coenen, L. 2015 The Geography of Sustainability Transitions: Review, synthesis and reflections on an emergent research field, Environmental Innovation and Societal Transitions, 17, $92-109$.

Hardy, D., 2000. Utopian England: Community Experiments 1900 - 1945. E \& FN Spon, London.

Harman, C., 1988. The First Last Time: 1968 and After. Cox and Wyman, Reading.

Heelas, P., 1996. The New Age Movement. Blackwell, Oxford.

Hegger, D. T. L., Van Vliet, J., Van Vliet, B., 2007. Niche Management and its Contribution to Regime Change: The Case of Innovation in Sanitation Technology Analysis \& Strategic Management 19, 729 - 46.

Heilscher, S., Seyfang, G., Smith, A., 2013. Grassroots innovations for sustainable energy: exploring niche development processes among community energy initiative, in Cohen, M., Brown, H., and Vergragt, P. J., (Eds) Innovations in Sustainable Consumption: New Economics, Socio-technical Transitions, and Social Practices, pp. 133 - 58. Edward Elgar, Cheltenham.

Heilscher, S. and Smith, S. 2014. Community-based digital fabrication workshops: A review of the research literature, Science and Technology Policy Research Unit (SPRU), University of Sussex, Working Paper Series, SWPS 2014-08. 
Hess, D. J., 2005. Technology and Product-Orientated Movements: Approximating Social Movement Studies and Science and Technology Studies Science, Technology and Human Values 30, 515 - 35.

Hess, D. J., 2007. Alternative Pathways in Science and Industry. MIT Press, London. Hodkinson, S., Chatterton, P., 2006. Autonomy in the city? Reflections on the social centres movement in the UK, City $10305-15$.

Hodson, M., Marvin, S. 2009. Cities mediating technological transitions: understanding visions, intermediation and consequences, Technological Analysis \& Strategic Management 21, $515-34$.

Hodson M., Marvin, S. 2010. Can cities shape socio-technical transitions and how would we know if they were? Research Policy, 39, 477 - 485.

Hoogma, R., Kemp, R., Schot, J., Truffer, B. 2002. Experimenting for Sustainable Transport, Spon Press, London.

Hopkins, R., 2008. The Transition Handbook Green Books, Totnes

Ilbery B., Watts D., Simpson, S., Gilg A., Little J. 2006. Mapping local foods: evidence from two English regions, British Food Journal 108, 213 - 25.

Jones. M., 2009. Phase space: geography, relational thinking, and beyond, Progress in Human Geography 33, 487 - 506.

Kemp, D., 2004. New Age: A guide Edinburgh University Press, Edinburgh.

Kemp, R., 2010. The Dutch energy transition approach International Economics and Economic Policy 7291 - 316

Kemp, R., Schot, J., Hoogma, R., 1998. Regime Shifts to Sustainability Through Processes of Niche Formation: The Approach of Strategic Niche Management Technology Analysis \& Strategic Management 10, 175 - 98.

Kockel, U., 1991. Countercultural Migrants in the West of Ireland in King, R. (Ed) Contemporary Irish Migration, pp. 70 - 82. Geographical Society of Ireland, Dublin.

Langley, A., 1999. Strategies for Theorizing from Process Data, Academy of Management Review 24, 691 - 710.

Langley A., Smallman C., Tsoukas, H., Van De Ven, A., 2013. Process studies of change in Organization and Management: Unveiling temporality, activity and flow, Academy of Management Journal 56, 1 - 13.

Law, J., Mol, A., (Eds) 2006. Complexities. Duke University Press London.

Ley, D., 1996. The new middle class and the remaking of the central city, Oxford University Press, Oxford. 
Longhurst, N. 2011. Twinned with Narnia? The postcapitalist possibilities of a countercultural place. PhD Thesis, Geography Department, University of Liverpool.

Longhurst, N. 2012. The Totnes Pound: A grassroots technological niche, in Davies, A. (Ed) Enterprising Communities: Grassroots Sustainability innovations, Emerald, Bingley, $163-188$.

Longhurst, N. 2013. The emergence of an alternative milieu: conceptualising the nature of alternative places, Environment and Planning A, 45, 2100 - 2119.

Lounsbury, M., Venresca, M., Hirsch, P., M (2003) Social movements, field frames and industry emergence: a cultural political perspective on US recycling Socio-Economic Review 1, 71 - 104.

Maillat, D., 1995. Territorial dynamic, innovative milieus and regional policy, Entreprenurship and Regional Development 7, 157 - 65.

Maillet, D., Lecoq, B., Nemeti, F., Pfister, M., 1995. Technological District and Innovation: The Case of the Swiss Jura Arc, Regional Studies, 29, 251 - 263.

Markard, J., Raven, R. and Truffer, B. 2012. Sustainability transitions: An emerging field of research and its prospects, Research Policy 41, 955 - 67.

McAdam, D., 1986. Recruitment to high-risk activism: the case of freedom summer, American Journal of Sociology 92, 64 - 90.

McKay, G., 1996. Senseless acts of Beauty: Cultures of Resistance since the Sixties Verso, London.

McKay, G. (Ed) 1998. DIY Culture: Party and Protest in Nineties Britain Verso, London.

Michell, J., 1983. The New View Over Atlantis, Thames and Hudson, London.

Mollison, B., 1997. Permaculture: A designers manual. Tagari publications, Tyalgum, Australia.

Monaghan, A., 2009. Conceptual niche management of grassroots innovation for sustainability: The case of body disposal practices in the UK Technological Forecasting and Social Change 76, $1026-43$.

Moilanen, J. 2012. Emerging hackerspaces - Peer production generation, International Conference on Open Source Systems: Long Term Sustainability, Hammamet, Tunisia.

Moulaert, F., and Sekia, F., 2003. Territorial Innovation Models: A Critical Survey, Regional Studies 37, 289 - 302.

Nicholls, W., 2009. Place, networks, space: theorising the geographies of social movements, Transactions of the Institute of British Geographers 34, 78 - 93.

Phillips, A. 2008. Holistic Education: Learning from Schumacher College, Dartington, Green Books.

Phillips, M., Raspberry, S., 1981. Honest Business Random House London. 
Pickerill, J., Chatterton, P., 2006. Notes towards autonomous geographies: creation, resistance and self-management as survival tactics, Progress in Human Geography 30, $730-46$

Pickerill, J., Maxey, L., (Eds) 2009a. Low Impact Development: The future in our hands. Downloaded from http://lowimpactdevelopment.wordpress.com

Pickerill, J., Maxey, L., 2009b. Geographies of Sustainability: Low Impact Developments and Radical Spaces of Innovation, Geography Compass 3/4, 1515 - 39.

Raven, R., 2012. Analysing Emerging Sustainable Energy Niches in Europe, in Verbong, G., and Loorbach, D. (Eds) Governing the Energy Transition, pp. 125 - 51. Routledge, Abingdon.

Raven, R., Schot, J., Berkhout, F., 2012. Space and scale in socio-technical transitions, Environmental Innovations and Sustainability Transititions, 4, 63 - 78.

Raven, R., Heiskanen, E., Lovio R., Hodson, M., Brohmann B., 2008. The Contribution of Local Experiments and Negotiation Processes to Field-Level Learning in Emerging (Niche) Technologies, Bulletin of Science, Technology and Society 28, 464 - 77.

Raven, R., Van Den Bosch, S., Weterings, R., 2010. Transitions and strategic niche management: towards a competence kit for practitioners Journal of Technology Management 51, 57 - 74.

Rip, A., 2012. The Context of Innovation Journeys, Creativity and Innovation Management 21, 158 - 70.

Rogers, E. M., 2003. Diffusion of Innovations, Free Press, London.

Rohracher, H., Späth, P., 2013. The Interplay of Urban Energy Policy and Socio-technical Transitions: The Eco-cities of Graz and Freiburg in Retrospect, Urban Studies.

Routledge, P., 2003. Convergence space: process geographies of grassroots globalization, Transactions of the Institute of British Geographers 28, 333 - 49.

Schot, J., Geels, F. W., 2007. Niches in evolutionary theories of technical change, Journal of Evolutionary Economics 17, 605 - 22.

Schumacher, E. F., 1973 [1993]. Small is Beautiful. London, Vintage.

Sel Terre, 2004. 10 ans de S.E.L en France. http://www.selterre.info/article.php3?id_article=44 Last accessed 23/09/2014

Seyfang, G., Longhurst N., 2013. Desperately Seeking Niches: Grassroots innovations and niche development in the community currency field, Global Environmental Change, 23, $881-891$.

Seyfang, G., Haxeltine, A., 2012. Growing grassroots innovations: exploring the role of community-based initiatives in governing sustainable energy transitions, Environment and Planning C 30, 381 - 400. 
Seyfang, G., Smith, A., 2007. Grassroots innovations for sustainable development: Towards a new research and policy agenda, Environmental Politics 16, 584 - 603.

Shields, R., 1991. Places on the Margin: Alternative geographies of modernity Routledge, London.

Shuman, M. H., 2000. Going Local! Routledge, New York.

Siegle, L., 2011. Totnes: Britain's town of the future, The Observer, 6 February. http://www.theguardian.com/environment/2011/feb/06/totnes-transition-towns-ethicalliving last accessed 23/09/2014.

Smith, A., 2012. Civil Society in Sustainable Energy Transitions in Verbong, G. and Loorbach, D. (Eds) Governing the Energy Transition: reality illusion or necessity? , pp. 180 - 202. Routledge Abingdon.

Smith, A., Raven, R. 2012. What is protective space? Reconsidering niches in transitions to sustainability Research Policy 41, 1025 - 36.

Smith, A., Vos J.-P., Grin J., 2010. Innovation studies and sustainability transitions: The allure of the multi-level perspective and its challenges, Research Policy 39435 - 48.

Smith, R. Cooper, C. 2006. Exploring the Mystical in the Ancient History of Totnes. Self published, Available from South Devon Steiner School.

Smith, D. P., Phillips, D. A., 2001. Socio-cultural representations of greentrified Pennine rurality Journal of Rural Studies 17, 457 - 69

Starr, A. 2000. Naming the Enemy: Anti-corporate movements confront globalization. Zed Books, London.

Thrift, N. 1999. The Place of Complexity, Theory, Culture and Society, 16, 31 - 69.

Toke, D., 2011. Ecological modernisation, social movements and renewable energy, Environmental Politics 20, 60 - 77

Transition Town Totnes, 2008. A Celebration of Local Food Transition Town Totnes, Totnes

Truffer, B., 2003. User-led Innovation Processes: the Development of Professional Car Sharing by Environmentally Concerned citizens Innovation 16, 139 - 52.

Truffer, B., Coenen, L., 2012. Environmental Innovation and Sustainability Transitions in Regional Studies, Regional Studies 46, 1 - 12.

Truffer, B., Dürrenberger, G., 1997. Outsider Initiatives in the Reconstruction of the Car: The Case of Lightweight Vehicle Milieu's in Switzerland Science, Technology and Human Values 22, $207-34$.

Turner, F., 2006. From Counterculture to Cyberculture. University of Chicago Press, London.

Vedin, B., 2007. What Future Conceptual and Social Innovations?, Journal of Future Studies. 12, 91 - 100. 
Verhees, B., Raven, R., Veraart, F., Smith, A., Kern, F., 2012. Interrogating Protective Space: Shielding, Nurturing and Empowering Dutch Solar PV, Eindhoven Centre for Innovation Studies, Working Paper 12.04.

Vettel, E. J., 2006. Biotech: The Countercultural Origins of an Industry University of Pennsylvania Press, Philadelphia.

Watts, M., 2001. 1968 and all that... Progress in Human Geography 25, 157 - 88.

Whitfield P., 2004. The Earthcare Manual: A Permaculture Handbook for Britain and Other Temperate Countries Permanent Publications East Meon.

Wilk, R. R., 1996. Economies and Cultures Westview Press, Oxford.

Williams, C. C., 1995. Local Purchasing Schemes and Rural Development: an Evaluation of Local Exchange and Trading Systems (LETS) Journal of Rural Studies 12, 231 - 44.

Wolford, W., 2004. This Land is Ours Now: Spatial Imaginaries and the Struggle for Land in Brazil, Annals of the Association of American Geographers 94, 409 - 24.

Young, M., 1996. The Elmhirsts of Dartington. Dartington Hall Trust, Totnes. 